\title{
YWHAZ wt Allele
}

National Cancer Institute

\section{Source}

National Cancer Institute. YWHAZ wt Allele. NCI Thesaurus. Code C88205.

Human YWHAZ wild-type allele is located in the vicinity of 8q23.1 and is approximately 35 $\mathrm{kb}$ in length. This allele, which encodes 14-3-3 protein zeta/delta, plays a role in signal transduction. Amplification of the gene may be associated with both anthracycline resistance and metastatic recurrence in breast cancer. 